\title{
Is West Nile virus a potential cause of central nervous system infection in Brazil?
}

\author{
Cristiane N. Soares ${ }^{1,2}$, Mauro J. Cabral Castro 2,3, José M. Peralta3, \\ Marcos R.G. de Freitas', Marzia Puccioni-Sohler ${ }^{2,4}$
}

\begin{abstract}
Meningitis and encephalitis are complications of West Nile virus (WNV) infection. Although WNV is endemic in North America, the virus has recently been reported in Colombia and Argentina. Investigation of WNV in Brazil is important since this virus has never been studied previously in this country. Objective: To investigate the presence of WNV infection in viral encephalitis/meningitis cases of unknown etiology in the city of Rio de Janeiro, Brazil. Method: Thirty-seven adults with viral meningitis/encephalitis had their serum and CSF tested for WNV antibodies using the ELISA method. Results: Only one case was WNVpositive, but this case was also positive for dengue. The plaque reduction neutralization test distinguished infections, and was negative for WNV. Conclusion: WNV can be confused with dengue infection. Their symptoms and neurological picture are similar. We did not find WNV in any patients with encephalitis and meningitis in the city of Rio de Janeiro. Up to now, it has not been detected in Brazil.
\end{abstract}

Key words: viral, meningitis, encephalitis, dengue infection, West Nile virus, CSF.

Seria o vírus do Oeste do Nilo causa potencial de infecção no sistema nervoso central no Brasil?

\section{RESUMO}

Meningite e encefalite são complicações da infecção pelo vírus do Oeste do Nilo (VON). Embora o VON seja endêmico na América do Norte, recentemente o vírus foi descrito na Colômbia e Argentina. Sua pesquisa no Brasil é importante uma vez que o vírus nunca fora estudado antes em nosso país. Objetivo: Investigar a presença do VON em casos de meningite e encefalite viral de etiologia desconhecida, na cidade no Rio de Janeiro, Brasil. Método: Trinta e sete adultos com quadro de meningite/encefalite tiveram seu LCR e soro testados para anticorpos anti-VON, pelo método ELISA. Resultados: Apenas um caso obteve sorologia positiva para VON, mas a sorologia para dengue também fora positiva. O teste da neutralização por redução de placa foi utilizado para distinção entre as infecções, sendo negativo para VON. Conclusão: A infecção por VON pode ser confundida com a infecção pelo vírus da dengue, seus sintomas e quadro neurológico são similares. Nós não encontramos o VON em pacientes com meningite/ encefalite na cidade do Rio de Janeiro. Até o momento ele ainda não foi identificado no Brasil.

Correspondence

Cristiane N. Soares

Rua Santa Clara 50 / 908

22060-000 Rio de Janeiro RJ - Brasil

E-mail: cnsoares@predialnet.com.br

crist_nsoares@yahoo.com.br

\section{Support}

This work was supported by the Fundação de Amparo à Pesquisa do Rio de Janeiro (FAPERJ)

Received 24 November 2009 Received in final form 23 March 2010 Accepted 1 April 2010

Palavras-chave: viral, meningite, encefalite, dengue, vírus do Oeste do Nilo, líquido cefalorraquidiano.

West Nile virus (WNV) infection is caused by a flavivirus, a member of the Japanese encephalitis virus serocom- plex $^{1}$. It was first isolated from an infected person in Uganda, in 1937. From 1937 to 1990 , the virus was responsible for in-

${ }^{1}$ Neurology Service, HUAP/UFF (Antônio Pedro Hospital, Fluminense Federal University), Brazil; ${ }^{2}$ CSF Laboratory, Clinical Pathology Service, HUCFF/UFRJ (Clementino Fraga Filho Hospital, Rio de Janeiro Federal University), Brazil; ${ }^{3}$ Microbiology Institute, CCS/UFRJ (Rio de Janeiro Federal University), Brazil; ${ }^{4}$ Neurology Service/HUGG/UNIRIO (Gafrée Guinle Hospital, UniRio), Brazil. 
frequent human outbreaks in Israel and Africa. However, since the mid-1990s, the frequency and severity of WNV outbreaks have increased ${ }^{2}$. Since detection of the virus in New York City in 1999, it has caused more than 16,000 cases of human disease and more than 660 deaths in North America ${ }^{3}$. The virus is transmitted by the bite of an infected mosquito, and it infects birds, humans and equines equally. Mosquitoes become infected in late summer and then pose an infection threat to humans and birds. Consequently, tropical areas have great potential for transmission of the disease. The clinical picture can vary from subclinical infection to an illness that is usually characterized by fever, malaise, anorexia, nausea, vomiting, headache and myalgia, and it may last for three to seven days. A macular, papular or morbilliform exanthem is also seen ${ }^{4}$.

Neurological manifestations, including encephalitis and meningitis, are complications of WNV infections, in the same way as in dengue infection ${ }^{5,6}$. Encephalitis is the most common neurological manifestation ${ }^{7}$. In West Nile infection, meningitis and encephalitis may develop in approximately one in 150 infected individuals ${ }^{4}$. The clinical features of this neurological infection include diffuse flaccid paralysis, resembling Guillain-Barré syndrome (GBS), but with characteristics that would be unusual for this disease (pleocytosis on CSF and axonal and demyelinating lesions on electromyography) ${ }^{7}$. More rarely, ataxia and extrapyramidal signs, cranial nerve abnormalities, myelitis, optic neuritis, and polyradiculitis can be observed in WNV infection ${ }^{8}$.

The aim of the study was to search prospectively for the presence of West Nile antibodies in patients presenting with viral encephalitis or meningitis in Rio de Janeiro, Brazil. South America receives hundreds of migratory bird species from the Northern Hemisphere, many from areas where the virus has been detected ${ }^{9}$. In addition, Rio de Janeiro is a tourism center that receives people from all over the world and is in a tropical area where mosquito proliferation occurs. These factors make this city a potential area for a WNV epidemic.

\section{METHOD}

This study was prospective. We selected $37 \mathrm{immu-}$ nocompetent adult patients with clinical diagnoses of viral meningitis or encephalitis who were seen in two hospitals in the city of Rio de Janeiro (Hospital de Clínicas de Niterói and Hospital Quinta D'or), between March 2006 and March 2008. We analyzed age, sex, clinical signs and symptoms on admission and CSF profile, and we looked for WNV antibodies in the CSF and serum. The study protocol was approved by the Ethics Committees of both hospitals, and all patients signed the informed consent form.

\section{Clinical diagnosis}

The criteria for acute meningitis included: $[\mathrm{A}]$ acute ( $<3$ weeks' duration) onset of symptoms such as headache, fever and nuchal rigidity; [B] CSF parameters (cell count $>5$ cells $/ \mathrm{mm}^{3}$, glucose ratio $>45 \mathrm{mg} / \mathrm{dl}$ and negative bacteriological/fungal investigations) ${ }^{10}$.

The patients were diagnosed as having encephalitis if they had fever and acutely altered consciousness/personality, seizures or focal neurological signs ${ }^{11}$. A normal cell count on CSF did not rule out the diagnosis of encephalitis, since there have been reports that it can be normal in $5 \%$ of such cases ${ }^{12}$, but all bacteriological and fungal cultures had to be negative. All patients underwent spinal tap on the day of admission and their serum was collected at the same time.

\section{Laboratory assays}

Routine CSF analysis - Routine CSF analysis was performed in a reference CSF laboratory (Neurolife) located in Rio de Janeiro. The total cell count was determined using a Fuchs-Rosenthal chamber, and differential cytology was determined by means of cell sedimentation. The CSF protein and glucose levels were analyzed by spectroscopy. Immunological tests were performed for syphilis (VDRL), HTLV-1 (human T-cell leukemia virus-1), Herpes simplex, Varicella zoster, cytomegalovirus and HIV1/2 antibodies (enzyme-linked immunosorbent assay - ELISA), and bacterial and fungal cultures were produced.

Screening for IgM antibodies for WNV - The CSF and serum of all patients were screened for anti-WNV antibodies using ELISA (PANBIO, Brisbane, Australia). The serum was diluted (1:100) in accordance with the manufacturer's recommendation. In order to increase the sensitivity of the test for CSF, it was diluted (1:2). The WNV ELISA test on CSF has a sensitivity of $95 \%$ and specificity of approximately $92.4 \%{ }^{13}$.

Laboratory criteria for WNV positivity - WNV was diagnosed by the presence of anti-WNV IgM in the serum or CSF. If the immunological tests were positive for WNV, the tests were repeated and dengue IgM antibody was tested because of possible cross-reaction. The plaque reduction neutralization test for WNV was performed when there were positive tests for WNV and dengue virus.

\section{RESULTS}

Thirty-seven patients fulfilled the criteria: 20 patients for viral meningitis and 17 for viral encephalitis. There were 12 males and eight females with a diagnosis of meningitis, with an average age of 32.2 years (standard deviation of \pm 12.5 years). All patients presented headache. Vomiting were present in $50 \%$ of the cases and nuchal rigidity in $55 \%$. The average CSF pleocytosis was 169 cells $/ \mathrm{mm}^{3}$ 
(standard deviation of \pm 176.8 cells $/ \mathrm{mm}^{3}$ ) and high CSF protein levels were found in $80 \%$ of the cases (average of $65 \mathrm{mg} / \mathrm{dl}$ and standard deviation of $\pm 34.6 \mathrm{mg} / \mathrm{dl}$ ).

The average age of the patients with encephalitis was 48.7 years (standard deviation of \pm 27.6 years) and the male/female ratio was $12 / 5$. The commonest symptom was seizures $(70.5 \%)$. Altered consciousness and headache were each present in $58.8 \%$ of the cases. Focal neurological signs/symptoms were present in four patients. The average cellularity in CSF in this group was 20.7 cells/ $\mathrm{mm}^{3}$ (standard deviation of \pm 34.7 cells $/ \mathrm{mm}^{3}$ ), and high CSF protein levels were found in $52.9 \%$ of the cases (average of $49.5 \mathrm{mg} / \mathrm{dl}$ and standard deviation of $\pm 31.1 \mathrm{mg} / \mathrm{dl}$ ).

One case of encephalitis had WNV IgM antibodies in the serum, found using the ELISA test. He was 32 years of age and presented fever, myalgia and three episodes of complex partial seizures. The neurological examination was normal. The symptoms lasted four days. Since WNV was positive in the serum, dengue serological tests were performed, which were also positive. However, the plaque reduction neutralization test for WNV (FDA/USA) was used to distinguish serological cross-reactions, and it was negative for WNV.

\section{DISCUSSION}

WNV is endemic in the USA, with approximately 19,525 cases reported from 1999 to 2007 , and $44 \%$ of these cases involved neurological impairment ${ }^{14}$. Until recently, WNV had only been seen in isolated reports of cases in Latin America. Between 2001 and 2004, case reports were cited in Mexico, Belize, Guatemala, El Salvador, Cuba, the Bahamas, the Cayman Islands, Jamaica, the Dominican Republic, Trinidad and Tobago, Puerto Rico and Colombia ${ }^{15}$. Recently, WNV was found in Argentina, causing infection in birds and neurological disorders in three horses ${ }^{16,17}$.

In our country, approximately 97 species of birds migrate from the northern hemisphere, and 18 species perform vertical displacement between southeastern Brazil and the Andes ${ }^{9}$. Because of bird migration and mosquito proliferation, virus monitoring is fundamental in our country, in order to prevent potential virus dissemination.

Only one of our cases of encephalitis was positive for WNV according to ELISA IgM in the serum. The WNV ELISA test was used in spite of the possibility of using PCR and viral culture because of the low sensitivity of these last two tests, which precludes their use as routine screening tests ${ }^{8}$. In addition, detection of IgM antibodies for WNV in serum or CSF is the most efficient method for diagnosing $\mathrm{WNV}^{7}$. Our case presented cross-reactivity for dengue and WNV, showing that it can be confused with dengue virus, both clinically and by laboratory methods. WNV was discarded as a diagnosis by the plaque re- duction neutralization test. Overall cross-reactivity between the IgM ELISA and flavivirus has been described in $12 \%$ of cases $^{18}$. The reasons for the low morbidity and mortality in Latin America are unclear. Some hypotheses include protection by antigenically cross-reactive flavivirus, decreased virulence of the circulating virus, high biodiversity in tropical regions leading to a dilution effect, and low levels of surveillance and diagnostic efforts ${ }^{14}$.

Finally, the most important point in this study is that, for the first time, WNV was investigated in patients who were previously healthy and developed meningitis and encephalitis. With the recent WNV activity in Argentina, it is fundamental to continue to monitor for this virus as an emerging cause of neurological disease in South America. Up to now, it has not been detected in Brazil.

ACKNOWLEDGEMENTS - The authors thank Dr Maria Rios from the Food and Drug Administration (FDA, Bethesda, USA) for providing the plaque reduction neutralization test for WNV (FDA/USA). The authors have no competing interest to declare.

\section{REFERENCES}

1. Romero JR, Newland JG. Viral meningitis and encephalitis: traditional and emerging viral agents. Semin Ped Infect Dis 2003;14:72-82.

2. Petersen LR, Marfin AA. West Nile virus: a primer for the clinician. Ann Intern Med 2002;137:173-179.

3. Hayes EB, Sejvar JJ, Zaki SR, Lanciotti RS, Bode AV, Campbell GL. Virology, pathology, and clinical manifestations of West Nile virus disease. Emerg Infect Dis 2005;11:1174-1178.

4. Hubálek Z, Halouzka J. West Nile Fever: a reemerging mosquito-borne viral disease in Europe. Emerg Infect Dis 1999;5:643-649.

5. World Health Organization (WHO). In: Dengue hemorrhagic fever: diagnosis, treatment, prevention and control. Geneva: WHO, 1997:1-87.

6. Solomon T, Dung NM, Vaughn DW, et al. Neurological manifestations of dengue infection. Lancet 2000;335:1053-1058

7. Petersen LR, Roehrig JT, Hughes JM. West Nile virus encephalitis. N Engl J Med 2002;347:1225-1226.

8. Tyler KL. West Nile virus encephalitis in America. N Engl J Med 2001;344: 1858-1859.

9. Rappole JH, Derrickson SR, Hubálek Z. Migratory birds and spread of West Nile virus in the Western hemisphere. Emerg Infect Dis 2000;6:319-328.

10. Kupila L, Vuorinen T, Vainionpää R, Hukkanen V, Marttila RJ, Kotilainen P. Etiology of aseptic meningitis and encephalitis in an adult population. Neurology 2006;66:75-80

11. Steiner I, Budka H, Chaudhuri A, et al. Viral encephalitis: a review of diagnostic methods and guidelines for management. Eur J Neurol 2005;12: 331-343.

12. Kennedy PG. Viral encephalitis: causes, differential diagnosis, and management. J Neurol Neurosurg Psychiatry 2004;75:10-15.

13. Malan AK, Martins TB, Hill HR, Litwin CM. Evaluations of commercial West Nile virus immunoglobulin $\mathrm{G}(\mathrm{IgG})$ and IgM enzyme immunoassays show the value of continuous validation. J Clin Microbiol 2004;42:727-733.

14. Kramer LD, Li J, Shi PY. West Nile virus. Lancet 2007;6:171-182.

15. Komar N, Clark GC. West Nile virus activity in Latin America and the Caribbean. Rev Panam Salud Publica 2006;19:112-117.

16. Morales AM, Barrandeguy M, Fabbri C, et al. West Nile virus isolation from equines in Argentina, 2006. Emerg Infect Dis 2006;12:1559-1561.

17. Diaz LA, Komar N, Visintin A, et al. West Nile Virus in birds, Argentina. Emerg Infect Dis 2008;14:689-690.

18. Hogrefe WR, Moore R, Lape-Nixon M, Wagner M, Prince HE. Performance of immunoglobulin $\mathrm{G}(\mathrm{lgG})$ and IgM enzyme-linked immunosorbent assays using a West Nile virus recombinant antigen (preM/E) for detection of West Nile virus- and other flavivirus-specific antibodies. J Clin Microbiol 2004:42:4641-4648 